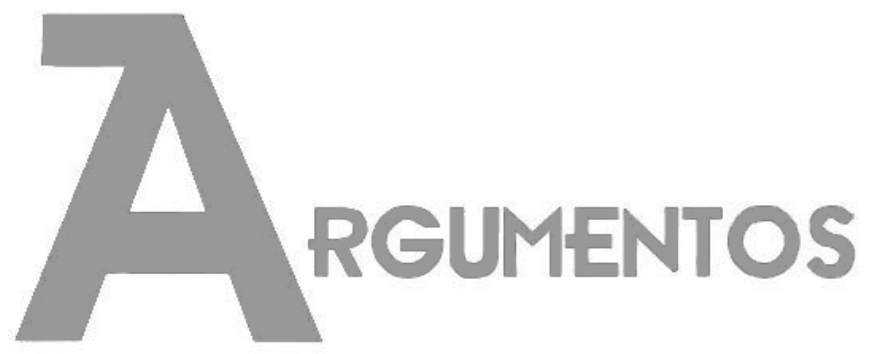

Vol. 16, n. 1, jan./jun. 2019 ISSN: 2527-2551 (online)

http://www.periodicos.unimontes.br/argumentos

\title{
O bairro como projeto e processo: a inscrição do bairro Frei Damião na cidade de Juazeiro do Norte-CE
}

\author{
Antonio Lucas Cordeiro Feitosa ${ }^{1}$
}

Recebido em: 11/02/2019

Aprovado em: 30/04/2019

\begin{abstract}
Resumo: $O$ artigo analisa a constituição do lugar social do bairro Frei Damião, na cidade de Juazeiro do Norte-CE, isto é, sua integração e inscrição na cidade. Para tanto, reconstituímos o movimento social que organizou a ocupação que contribuiu com a formação do bairro. A reflexão também abrange a classificação do bairro como "área de vulnerabilidade social", os sentidos de suas diferentes nomeações, a segmentação do seu espaço e sua desqualificação como periferia. Beneficiamo-nos de entrevistas com moradores do bairro e lideranças do movimento social; analisamos leis municipais, documentos do movimento social e estudos acadêmicos que tratam do local. Seja a partir da posse inicialmenteilegal da propriedade ou dos discursos que classificam o bairro Frei Damião como de "risco social" e periferia, seu lugar de inscrição na cidade são suas margens físicas e simbólicas.

Palavras-chave: Periferia; Movimento social urbano; Segmentação socioespacial.
\end{abstract}

\section{El barrio como proyecto y proceso: la inscripción del barrio Frei Damião en la ciudad de Juazeiro do Norte-CE}

Resumen: El artículo analiza la constitución del lugar social del barrio Frei Damião en la ciudad de Juazeiro do Norte-CE, esto es, su integración e inscripción en la ciudad. Para ello, reconstituimos el movimiento social responsable por organizar la ocupación que con tribuyócon la formación del barrio. La reflexión, además, abarca la clasificación del barrio como "zona de vulnerabilidad social", los sentidos de sus distintos nombramientos, la segmentación de su espacio y su descalificación como periferia. Nos proveímos de entrevistas con los residentes del barrio y con liderazgos del movimiento social; analizamos leyes municipales, documentos del movimiento social e investigaciones académicas sobre el local. Sea desde la posesión al principio ilegal de la propiedad o de los discursos que clasifican el barrio Frei Damião como de "riesgo social" y periferia, su lugar de inscripción en la ciudad son sus márgenes físicos y simbólicos. Palabras-clave: Periferia; Movimiento social urbano; Segmentación socioespacial.

\footnotetext{
${ }^{1}$ Doutorando e Mestre em Sociologia pela Universidade Federal do Ceará - Fortaleza, Brasil. E-mail:< cordeirofeitosa@gmail.com >. ORCID: https://orcid.org/0000-0003-4211-0059.
} 


\title{
The neighborhood as project and process: the establishment of Frei Damião neighborhood in the city of Juazeiro do Norte, Brazil
}

\begin{abstract}
This article analyzes the establishment of Frei Damião neighborhood as a social place in the city of Juazeiro do Norte, state of Ceará, Brazil, namely covering its formation and integration in the city. To do so, we traced the social movement that organized the occupation that later led to the neighborhood. Reflection also considers the neighborhood's classification as an 'area of social vulnerability', the meanings of its different designations, the segmentation of space, and its social disqualification as a periphery. We benefit from interviews with neighborhood residents and leaders of the social movement; and we also analyzed municipal laws, documents of the social movement, as well as academic studies that had a focus in the neighborhood. Whether from the initially illegal property ownership, or from the discourses that classify the neighborhood of Frei Damião as a place of 'social risk' and periphery, its place of establishment in the city is constituted by physical and symbolic margins.
\end{abstract}

Keywords: Periphery. Urban social movement. Social and spatial segmentation.

\section{Introdução}

$\mathrm{O}$ artigo analisa alguns eventos relacionados à origem histórica e social do bairro Frei Damião, na cidade de Juazeiro do Norte-CE. Iniciado a partir de ocupação coletiva de uma propriedade então pertencente a Igreja Católica, em 1990, entendemos que esse evento, organizado pelo Movimento dos Sem Teto de Juazeiro do Norte (MST), juntamente com outros, está articulado com a inscrição social do bairro na cidade, sua desqualificação e classificação como periferia. Essa inscrição ocorreu a partir do modo como esses acontecimentos repercutiram na constituição da imagem criada sobre o local. Assim, analisaremos as implicações que as ações promovidas pelo movimento social que projetou o bairro tiveram para sua inscrição na cidade, no imaginário urbano, e na forma como essas implicações foram e são organizadas e negociadas, seja a partir das diferentes nomeações do bairro, seja por meio da relação que os moradores estabelecem com o espaço, segmentando-o em territorialidades nomeadas e caracterizadas de formas distintas.

A problematização que orienta a análise tem por base a relação entre o acesso à moradia e o acesso à cidade (MENEZES, 2018). Com base nisso, podemos elencar alguns questionamentos: se for verdadeira a assertiva de que o acesso à moradia dá acesso à cidade, que lugar o bairro Frei Damião e seus habitantes têm na cidade de Juazeiro do Norte? Que lugar foi criado para o bairro a partir do movimento social e a ocupação coletiva de terras que o originou? Logo, o problema ecoa na seguinte questão: “[...] 
como as práticas coletivas originadas de determinados segmentos da sociedade (os favelados) e articuladas basicamente (mas não apenas) em torno da questão fundiária e da apropriação da cidade por seus moradores afetam o padrão de integração social e são por ele afetadas?" (MACHADO DA SILVA, 2002, p. 222). Com essa perspectiva, o trabalho está alinhado à abordagem que propõe pensar as práticas dos movimentos sociais não somente em termos internos, mas externos também, ou seja, no que "resultam", mesmo que de modo não intencional, e como "afeta[m] os padrões de sociabilidade e integração sistêmica" (Ibidem). Assim, a integração à cidade é mesmo almejada pelos que promoveram as ações relacionadas ao MST e que resultaram na constituição do bairro, seja pela luta por moradia, seja no esforço de constituição de um "bairro" e não uma "favela", como se verá. Por outro lado, atos de administração da cidade foram significando o bairro de forma distinta ao longo da sua história.

Outra orientação tomada no estudo do movimento social que ensejou a constituição do bairro diz respeito à compreensão do lugar de experiências biográficas e de uma dimensão mística-religiosa nos fluxos de acontecimentos que culminaram com o seu surgimento.

Para tanto, o artigo, fruto de pesquisa desenvolvida entre os anos de 2012 e 2014, analisa entrevistas realizadas com sujeitos que estiveram envolvidos no movimento social que deu origem ao bairro e/ou que moram no local; documentos legislativos do município de Juazeiro do Norte e do movimento social (leis municipais, regimento do MST, manifesto/projeto habitacional elaborado pelo MST, abaixo-assinado), e monografias elaboradas sobre o bairro ${ }^{2}$.

\section{O bairro como projeto e processo}

Em 2010, ano do último recenseamento brasileiro, o bairro Frei Damião era o terceiro maior bairro da cidade de Juazeiro do Norte, em números de habitantes, com 14.677 moradores (IBGE, 2016). Sendo um dos 36 bairros da cidade, desde sua origem, em 1990, tem sido associado no imaginário urbano local à "pobreza", "violência" e "risco

\footnotetext{
${ }^{2}$ A pesquisa da qual este artigo resulta foi desenvolvida durante o período que cursei o mestrado em sociologia. Agradeço à CAPES, pela concessão da bolsa de estudo, e à professora Teresa Cristina Furtado Matos (PPGS/UFPB), por ter me orientado. Também agra deço à(ao) parecerista anônima(o) da Revista Argumentos, pelas considerações pertinentes.
} 
social" e é comumente desqualificado e classificado pelos habitantes da cidade como periferia.

Embora não seja o único bairro da cidade assim qualificado, juntamente com os bairros João Cabral (17.859 habitantes, mais populoso da cidade) e Pio XII (11.099 habitantes), é um dos mais recorrentes nos processos de tipificação ensejados nas conversas informais e pelos veículos de comunicação locais que elaboram e divulgam classificações dos "bairros mais violentos" com base no número de homicídios por estes últimos registrados.

Esse nexo entre violência e periferia na produção da desqualificação de um lugar como periferia, no caso do bairro Frei Damião, é antecedido pelo projeto e processo que resultou na sua origem ${ }^{3}$.

Localizado na cidade de Juazeiro do Norte, cuja emancipação política ocorreu em 1911 e que integra a Região Metropolitana do Cariri, ao sul do estado do Ceará, a história do bairro está entrelaçada com a história da cidade. Tendo a terceira maior população urbana do Ceará (240.128 habitantes, de um total de 249.939), Juazeiro do Norte é conhecida pelos significados que mobiliza em devotos do Padre Cícero; significados estes que atraem para a cidade milhares de romeiros ao longo do ano ${ }^{4}$. A partir da consagração do padre como santo, seus devotos passarama fazer-lhe doações, o que incluía propriedades rurais (MENEZES, 1997). Em testamento de 1923, o padre destinou os bens que integravam seu patrimônio a pessoas, igrejas existentes em Juazeiro do Norte, como a de Nossa Senhora do Perpétuo Socorro e Nossa Senhora das Dores, sendo

\footnotetext{
${ }^{3}$ A partir da abordagem processual de Elias (2008, ELIAS; SCOTSON, 2016), o termo processo é adotado mediado por algumas dimensões que o significam: ênfase no relacional; como um dar forma, mais do que a forma, o resultado; a partir de aspectos de mudança e historicidade; como sendo constituído a partir de uma causalidadecircular existente entre diferentes elementos que são articulados e se retroalimentam, criando multicausalidades. Já a noção de projeto é inspirada em Velho (1999) e está relacionada aqui a uma ação/ideia organizada coletivamente, criada mais racionalmente e conscientemente e com a intenção de atingir determinados objetivos dentro do "campo de possibilidades" existente.

4 Padre Cícero Romão Batista (1844-1934) foi um líder religioso e político. Ganhou notoriedade, sobretudo, por ter protagonizado, juntamente com a beata Maria de Araújo, um dos episódios mais conhecidos da cidade e que a constituiu como um dos centros de romaria mais significativos do Brasil, dada à quantidade de devotos que afluem para a cidade todos os anos. Esse episódio ficou conhecido como "o milagre da hóstia", no qual a hóstia dada pelo Padre Cícero à beata Maria de Araújo, durante celebração ecumênica, se transformou em sangue. Ocorrido pela primeira vez em março de 1889, o evento repetiu-se durante dois anos, desencadeando as primeiras romarias à Juazeiro do Norte e tornando o Padre Cícero um santo do catolicismo popular e não reconhecido como santo pela Igreja Católica (DELLA CAVA, 1976).
} 
esta última desde sempre a igreja matriz do município, e a Congregação Salesiana ${ }^{5}$. Além disso, indivíduos de diferentes lugares, especialmente do Nordeste, passaram a significar Juazeiro como "terra santa", "terra da mãe de Deus", adotando-a como nova moradia. Esses elementos místicos-religiosos vinculados à cidade também estão presentes nos eventos que resultaram na formação do bairro Frei Damião, em parte porque neles foram mobilizados.

Segundo nossos interlocutores, em Juazeiro do Norte o debate sobre o direito à habitação foi introduzido pelo padre salesiano Pedro Lapo a partir da sua atuação junto às Comunidades Eclesiais de Base (CEB's), as quais ele ajudou a constituir na cidade, na segunda metade da década de 80. De acordo com Chico Gomes, que foi presidente do MST em 1990, para Pedro Lapo, as propriedades deixadas em testamento por Padre Cícero para a Igreja Católica deveriam ser utilizadas pela "Igreja para amparar todos os pobres da região Nordeste, seja para trabalhar na terra, porque era muita terra, tinha a zona rural, seja para morar na cidade".

Chico Gomes e outras lideranças do MST estiveram vinculados não somente ao Movimento, mas igualmente engajados nas ações das CEB's e do Partido dos Trabalhadores (PT), que existe na cidade desde 1980.

Se fora padre Lapo que fomentou, antes de deixar a cidade, a ideia de utilizar as terras que padre Cícero repassou ao patrimônio da Igreja para "amparar os pobres do Nordeste", a organização do movimento que realizou esse ideal se deu por intermédio da reunião de alguns membros das CEB's e do PT, tendo os primeiros participado da constituição do partido.

Além disso, Chico Gomes localiza sua participação em movimentos de "luta por moradia" na cidade de São Paulo, seu retorno a Juazeiro do Norte, em 1984, e sua participação (março de 1990) em um congresso da Corrente do Trabalho, da qual era membro no âmbito do PT, como importante para a disseminação das ideias em torno da "luta por moradia", em Juazeiro do Norte, e para a organizaçã o do MST.

Segundo ele, ao retornar a Juazeiro do Norte depois do congresso, propôs aos integrantes do PT a criação de um movimento de reivindicação por moradia na cidade. Inicialmente, alguns membros do partido acreditaram que a ideia não era viável na

\footnotetext{
${ }^{5}$ A Congregação Italiana dos Padres Salesianos é uma organização pertencente à Igreja Ca tólica, fundada por Dom Bosco na segunda metade do século XIX, na Itália.
} 
cidade. Mesmo assim, Chico Gomes diz que começou a organizar reuniões e um cadastro das pessoas que "moravam em quartins [diminutivo da palavra "quartos" na linguagem local], casa alugada, o pessoal das vilas".

A partir de maio de 1990, o movimento já se encontrava constituído e suas finalidades definidas em Regimento Interno, sendo uma delas: "a- Organizar todas as famílias de sem teto, para buscar soluções para o problema da habitação".

No decorrer de 1990, organizou-se um cadastro, que chegou a registrar 3.500 famílias, e três manifestações que tomaram as ruas da cidade e objetivavam reivindicar, junto ao poder executivo municipal, moradias para as famílias cadastradas no movimento. Em um desses encontros, as lideranças do movimento apresentaram ao prefeito e distribuíram à população da cidade o "manifesto" que denominaram de "Projeto alternativo habitacional da população de Juazeiro do Norte" (LIMA, 2001). O documento continha um conjunto de reivindicações centradas na questão da moradia, mas também relacionava outros temas associados, uma vez considerando o perfil dos integrantes do MST ("serventes, doméstica, sapateiros, ferreiros, funcionários públicos municipais, feirantes, comerciários, artesãos, enfim, empregados e desempregados"). No texto podemos encontrar o nome Mutirão da Vida, evocado para se referir ao projeto habitacional que o Movimento apresentava e para nomear o futuro local onde morariam. Como se verá, essa foi uma das denominações do bairro e que ainda coexiste com a nomeação atual.

Na primeira reunião das lideranças do movimento com o prefeito municipal, este assumiu como compromisso verificar a viabilidade de a Prefeitura Municipal comprar áreas para construção de habitações para as famílias cadastradas no MST. Todavia, em encontro seguinte, realizado no mês de setembro, o prefeito comunicou que os recursos municipais disponíveis eram insuficientes para a compra da propriedade.

Após essa reunião, Chico Gomes, então presidente do Movimento, afirmou que direcionou as pessoas que estavam no pátio da prefeitura para sua casa. Segundo ele, ali anunciou que no dia 27 de setembro viessem todos à sua casa, pois no final da tarde daquele dia iriam para a "terra". Para as lideranças do Movimento, nesse momento se pensava em três possibilidades de ocupação. Uma seria na área em que a prefeitura construiria a rodoviária municipal; outra era uma propriedade do bispo; e a terceira eram as "terras de Nossa Senhora das Dores", uma propriedade rural que fora doada 
por Padre Cícero ao patrimônio da igreja matriz da cidade, que leva o nome da santa. No caso da primeira propriedade, as lideranças do movimento avaliaram que a área era insuficiente para abrigar as famílias cadastradas e sua ocupação causaria uma "polarização com o poder público". A segunda área já havia sido vendida, e sobre a última só se sabia da sua existência (mencionada por Padre Lapo), mas não da sua localização. Assim, embora decidido a ocupar "as terras de Nossa Senhora das Dores", o presidente do MST não conhecia onde ficava a propriedade. Foi um morador da área que informou a Chico Gomes a localização do imóvel.

Segundo Chico Gomes, além da grande extensão dessa área, ele a avaliou como viável à ocupação uma vez que "lá [era] a terra de Nossa Senhora, [era] a terra da mãe, [era] a terra dos filhos". Por outro lado, ele disse ter ponderado que caso fosse empregado o uso da violência contra o povo, a igreja e o padre responsável pela propriedade se comprometeriam.

No final da tarde de 27 de setembro de 1990, uma quinta-feira, uma multidão formada por mais de mil pessoas saiu da casa de Chico Gomes. Levavam uma imagem de Nossa Senhora da Conceição (a única que conseguiram naquele momento, segundo Chico Gomes) em um andor em formato de casa de taipa. A "procissão" chegou a seu destino, "as terras de Nossa Senhora das Dores". Ali acamparam e passaram a noite. Logo deram início aos trabalhos para construção dos primeiros "barracos", feitos com lonas, palha, papelão e madeira.

A área que fora ocupada não corresponde à propriedade que posteriormente foi doada pela Igreja ao MST e que constituiu o bairro Frei Damião, embora ambas fizessem parte do que era o patrimônio da igreja de Nossa Senhora Dores. O local que foi ocupado estava localizado do lado norte da Avenida Padre Cícero, estando próximo a essa via; e hoje, o bairro está situado no lado sul da referida avenida e recuado em relação a ela6 . Esse deslocamento no espaço se deu como exigência do bispado, cuja sede é em Crato, para que fosse feita a doação da propriedade ao MST. Para Nininha, que fora uma das organizadoras do Movimento e integra a equipe da Comissão Pastoral da Terra (CPT) do Cariri cearense, essa mudança ocorreu uma vez que a propriedade ocupada era

\footnotetext{
${ }^{6}$ Trata-se de importante via de ligação entre os municípios de Juazeiro do Norte e Crato que, juntamente com Barbalha, integram o conurbado conhecido como Triângulo Crajubar, região que concentra a maior parte dos investimentos e serviços públicos e privados da Região Metropolitana do Cariri.
} 
"privilegiada", já que estava muito próxima à Avenida Padre Cícero. Por "não serem terras para sem teto", pois "terras de visibilidade", "o projeto era esconder mais, jogar esse povo para longe". Assim, chegou-se ao que os moradores denominam ainda hoje de Primeira Rua ou Rua da Capela, local onde foram construídas as primeiras habitações, distante cerca de um quilômetro e meio da Avenida Padre Cícero. Essa propriedade, onde atualmente se encontra o bairro, também pertencia à Igreja, uma vez que as "terras de Nossa Senhora das Dores" se estendiam do local inicial da ocupação até a divisão com o município de Barbalha, compreendendo uma área de grande extensão em formato retangular.

O padre que era o responsável pela propriedade resistiu à ocupação. Como disse Chico Gomes: "Ele chegou a dizer que quem permanecesse na terra não era romeiro da mãe de Deus, não era filho de Deus, não era filho da mãe de Deus. Chegou a dizer que as pessoas eram espírito de alicate, porque até as mangas verdes [existentes no local da ocupação] o povo estava comendo". "Desordeiros do padre Cícero invadem a terra da mãe de Deus", falava o padre durante seu programa de rádio, segundo seu De Jesus, que integrara o Movimento ${ }^{7}$.

Apesar dessa resistência, o movimento persistiu e a diocese autorizou o pároco a fazer a doação, o que ocorreu em novembro de 1990. A partir daí, foram distribuídos lotes entre as famílias cadastradas no MST.

Atualmente, pelo mapa municipal definido pela prefeitura, o bairro engloba três áreas (não distinguidas no mapa), sendo elas: a que foi doada pela igreja ao movimento; uma área que pertencia à Igreja, mas foi vendida em 1991, e uma propriedade particular adjacente. Nessa definição oficial-política-administrativa, o bairro abrange uma vasta região. Todavia, é nas duas primeiras áreas que se concentram densamente as habitações dos moradores (o restante do território definido pela prefeitura, que

\footnotetext{
7 Procurando compreender a repercussão que a ocupação teve na cidade e região, consultei os poucos jornais impressos de 1990 disponíveis nos acervos municipais, que são raros e de ca tal oga ção el ementar. Neles, encontrei apenas a pequena nota "PANTANAL JUAZEIRENSE", que informava: "A novena da invasão das terras da Paróquia de Nossa Senhora das Dores à margem da estra da Juazeiro/Crato ainda vai render muitos capítulos. O Padre Murilo [pároco da igreja de N. Sra. das Dores e responsável pela propriedade ocupada] diz que só negociará após a retirada dos invasores, enquanto que estes afirmam não arredar o pé do local. A Justiça deverá mandar expedir mandado de reintegração de posse à Igreja e a corda rebentará do lado do PT" (FOLHA DE JUAZEIRO, 1990, p. 5). Interessante destacar o uso do termo "pantanal", que em 1990 dava nome à novela transmitida pela TV Manchete e que era ambientada no Pantanal mato-grossense. Adiante, essa repercussão será retomada a partir de falas de Dona Sebastiana e Chico Gomes.
} 
engloba áreas que os moradores denominam de sítio, loteamento e conjunto e que para eles não pertencem ao bairro, é ocupado de forma dispersa e ainda conta com muitos espaços inabitados), sendo que a primeira compreende as áreas/territorialidades que os moradores denominam de Frei Damião e Baixa da Raposa; e a segunda a área nomeada de Vila Real.

Apresentado o que foi o MST em Juazeiro do Norte, agora podemos pensar sobre as consequências que esses eventos acarretaram, e acarretam ainda hoje, no bairro e nos seus moradores, no que repercutem na constituição da imagem do bairro ${ }^{8}$.

\section{A invenção da área de "risco social"}

A produção social do bairro Frei Damião, na cidade de Juazeiro do Norte, inicia quando se constitui como projeto coletivo e depois com a ocupação, que dá início à criação do seu lugar na cidade e que será continuamente revisto, como se verá adiante.

No momento da ocupação, os participantes foram congregados em uma área tipicamente rural ao ensejarem o direito à moradia e a "luta" pela "terra". A seguinte fala de Chico Gomes é emblemática sobre esse tipo de projeto humano:

Eu brincava com o povo: “Ó, o Padre Cícero colocou o nome Baixio das Almas [ao local onde hoje é o bairro Frei Damião] porque ele sabia que aqui ia se encher de alma". Que aqui era deserto, deserto do Saara, só tinha areia, mas, ele sabia que ia se encher de alma, mas almas vivas e que lutam pra viver, entendeu.

Ou, como conta dona Sebastiana, que integrou o MST e que na época desta pesquisa tinha 74 anos de idade e residia no bairro:

Aqui foi luta, meu filho, nós lutamos muito. Muitas das vezes eu queria fracassar por causa da pressão. Você não tem nada, porque a gente não comprou, ocupou, quando a gente tem a certeza assim aquele... Eu tinha aquele ressentimento, eu acho que eu não sou dona, porque eu não comprei. A gente se sente mal, mas por a necessidade eu digo: "eu não comprei, mas também eu não tomei de ninguém". Eu tomei de um dono que não precisa, então aqui é meu. Aíficava, aíia lutando. Mas a gente se senteacuado, chega um ponto que a gente fica num beco sem saída, é preciso ter muita coragem.

\footnotetext{
8 Para um maior detalhamento do MST e do contexto da época, ver Feitosa (2015), especialmente o capítulo 3.
} 
Essa "luta", essa ação política organizada, inscreveu fisicamente o bairro na cidade ao proporcionar a ocupação de uma propriedade privada e, assim, o inscreveu também socialmente ao ser o elemento inicial a partir do qual foi criada uma imagem a seu respeito. Cabe aqui compreender que imaginário foi criado em torno do bairro Frei Damião. Nesse ponto, tratamos da relação entre o bairro e a cidade, da forma como a cidade pensa o bairro.

Todo o processo de ocupação da propriedade que pertencia ao patrimônio da Igreja teve ampla visibilidade na cidade de Juazeiro do Norte. As passeatas até o prédio da prefeitura reuniam muitas pessoas e cruzavam as ruas centrais da cidade. A manifestação desse segmento da população, os "sem teto", e as formas que elegeram para divulgar e pressionar a administração municipal foram inspiradas nas experiências dos movimentos sociais existentes em cidades como São Paulo nas décadas de 70 e $80^{9}$. Lá, assim como em Juazeiro, o perfil dos que se engajaram nas lutas sociais, e que com elas esperavam ser beneficiados, pode ser descrito como "classe popular" 10 .

Oriundos dos recantos da cidade, morando em condições precárias, pagando aluguel e estando desempregados, esses sujeitos já eram prenunciados pelas condições econômicas e sociais em que se encontravam imersos, informados como "lupem, desempregadíssimo", como os caracterizou Nininha.

Com as manifestações que realizaram e com o desfecho do processo da ocupação, os participantes do movimento "ficaram na história", como contou Dona Sebastiana:

A nossa luta era por um teto, aí então ele [Chico Gomes] botou Mutirão da Vida [como nome do local], que a gente só pode dizer que tem vida, que tem lazer, que tem tudo quando tem uma casa. Aí, o povo começou a achar o nome feio. Aí, mudou para bairro Frei Damião. Lucas: Por que o pessoal achava feio? Sebastiana: Eu não sei, achavam que, eles achavam feio porque quando a gente chegou aqui chamavam os afavelados. O povo dizia... tinha medo do povo daqui. Quando uma pessoa chegava na rua [referência a espaços centrais na cidade] era discriminado, que dizia que morava no

\footnotetext{
${ }_{9}^{9}$ Sobre isso e um pouco do contexto nacional do período, ver Kowarick (1987).

10 Assim como em Durham (2004), emprego o termo "classes populares" com finalidades mais descritivas do que analíticas, identificando o perfil das pessoas cadastradas no MST e primeiros moradores do bairro. Como já mencionado, essas pessoas eram caracterizadas como as que "moravam em quartins [diminutivo de quartos], casa alugada, o pessoal das vilas", "serventes [de pedreiro], doméstica, sapateiros, ferreiros, funcionários públicos municipais, feirantes, comerciários, artesãos, enfim, empregados e desempregados".
} 
Mutirão, aí o povo não queria conversa, num dava apoio não, nem olhava, tinha medo, porque nós somos discriminados, nós ficamos na história como vandalismo, como bandidos, como desocupados. Foi assim a imagem que Carlos Cruz [prefeito municipal à época do movimento] e a família passou pra mídia, pra sociedade. Nós somos discriminados, somos um povo que foi afastado da sociedade. Nós sofremos aqui, sofremos humilhação, discriminação, nós sofremos muito. Mas quando eu chegava na rua que o povo dizia: "onde você mora?", eu dizia "no Mutirão". Eles olhavam pra baixo. Eu dizia: "o que foi, teve alguma coisa errada aí?' Aí: 'Mutirão!...', eu digo "nem roubo, nunca matei ninguém, nunca roubei e estou aqui, você tá vendo minha luta trabalhando e se existe alguém [morando no bairro] que você pensa que é desse tipo, foi da sua casa [que surgiu]". É assim mesmo meu filho, lá tem pessoa pobre, humilde, que não teve condições de construir sua casa aqui na rua.

"Ficaram na história", pois ganharam notoriedade a partir do movimento que provocaram na cidade; porque geraram um conflito moral e social ao tomarem para si uma propriedade privada e nela habitarem sem a posse legal, ao rivalizarem com Igreja Católica e sua autoridade, o padre; porque foram motivo de processos jurídicos; porque encamparam um movimento político com forte presença de partido de esquerda e demandas da classe popular.

A construção das primeiras habitações na área ocupada já era vista como "favela" pelos moradores dos bairros vizinhos: "Aí o povo dali não gostava, por motivo de dizer que era uma favela, afavelados" (Dona Sebastiana). Segundo Chico Gomes, a propriedade ocupada já havia sido predestinada, no testamento do Padre Cícero, aos pobres do Nordeste.

Se hoje o lugar do bairro Frei Damião na cidade já está consolidado, tal lugar, que não é meramente físico/geográfico, mas também moral, não está desmembrado da sua história. Se estiver, não deixa de ser atualizado pela ideia de pobreza e violência, pelo perfil de classe popular dos seus moradores, localizando-o como espaço exótico, imoral, caracterizado pela carência/falta, desordem e ilegalismo, violência e perigo, risco/vulnerabilidade social, um fantasma no imaginário urbano, tal como ocorre com outros contextos nacionais (ZALUAR; ALVITO, 2006). Como disseram nossos interlocutores:

Nininha: É, [o bairro Frei Damião] está ali ao lado do bairro mais nobre de Juazeiro, que é o Lagoa Seca. Então, enfrentar isso também não é uma coisa 
bonita, porque "Nossa, como aquilo, perto de nós". Lagoa Seca já era um bairro consolidado [à época da ocupação].

Lucas: A ideia de esconder o bairro, como você falou, era esconder o quê? [quando foi feita a remoção das pessoas da área ocupada para onde hoje se encontra o bairro].

Nininha: Era esconder o povo mesmo, era esconder aqueles miseráveis, a ideia era isso. São marginais, não precisam ser vistos. Então joga, esconde, mesmo porque lá vai ser uma grande favela. E eles apostaram nisso muito tempo, nem uma ajuda política estruturante para ali, ali são favelados e vai ser uma grande favela e é de bandidos, ainda hoje tem esse estigma. "É de onde? É do Mutirão? Ave Maria, Ave Maria três vezes". Então assim, o Mutirão, como todos os bairros de Juazeiro e todos os bairros de periferia de nosso país, tem gente do bem e tem gente do mal. Essa dualidade existe e vai existir em qualquer canto, seja na Lagoa Seca, seja no Mutirão.

Chico Gomes: Na época [da ocupação] a imprensa, acho que incentivada pelo município, pela prefeitura, que não tinha interesse, porque em tudo vai o interesse político, não tinha interesse que o Mutirão da Vida fosse adiante, porque era uma iniciativa que também tinha o dedo do PT, e tudo nessa vida vai a danada da política, aí chamavam de, apelidavam de a favela do bispo, a favela da santa, o pantanal. Tinha uma novela O Pantanal, aí chamavam lá de pantanal, que aí era um atoleiro [de areia], que aí só tinha gente que não presta. Mas quando eles usavam a palavra pantanal era pra denegrir mesmo a imagem da comunidade.

Enquanto Nininha afirma que a ideia daqueles que se opunham ao movimento era esconder o bairro, ao afastar os ocupantes da área de visibilidade que conquistaram nas proximidades da Avenida Padre Cícero, dona Sebastiana, como também citado anteriormente, diz que "fomos afastados da sociedade". As duas afirmações podem ser entendidas em função do recuo espacial em relação à importante avenida, que os moradores foram forçados a fazer no momento da negociação da doação da terra, e quanto à localização atual do bairro, que fica no limite intermunicipal de Juazeiro do Norte com os municípios de Barbalha e Crato.

Ainda nas falas de dona Sebastiana, Nininha e Chico Gomes, temos a descrição da imagem que a "rua", a cidade, seu centro, criou acerca do bairro. Podemos pensar sobre isso também a partir da circulação do bairro na/pela cidade. Essa ideia nos ajuda a pensar a relação entre o bairro e a cidade, entre seus moradores e demais habitantes de Juazeiro do Norte a partir do deslocamento dos primeiros por espaços e situações extrabairro. Voltemo-nos às pessoas do bairro e suas interações com/na "rua", "lá embaixo", "lá fora", "no centro": 
Suzana (17 anos e moradora do bairro - à época da pesquisa de campo): É uma coisa boa [ser moradora do bairro Frei Damião], apesar que quando a pessoa chega em alguns locais que diz "Eu moro lá no Frei Damião”, "Ah, sim, Mutirão". Aí eu: "É". Aí: "Eita, como lá é perigoso". Mas não, não é isso. Quem mora, quem convive com as pessoas daqui acha uma coisa totalmente diferente e eu gosto de morar aqui. Lucas: Mas já aconteceu com você a situação de chegar e dizer que mora no Mutirão? Suzana: Já. Quando eu costumo ir lá embaixo na casa de meus colegas, de minhas colegas, aí diz: "Ai, tu mora ali. Eita, como é longe", num sei o quê. Quando eu conheço alguém assim diferente, aí acontece isso. Lucas: Mas você usa qual dos nomes? Suzana: Frei Damião [ênfase]. Lucas: Você acha que alivia um pouco mais? Suzana: Acho que sim, que Mutirão ficou para trás e tudo.

Chico Gomes: Elá fora é todo mundo dizendo que aí só tem gente que não presta, que não sei o quê. E eu ando aí pra cima e para baixo só vejo boniteza.

Dona Helena ( 63 anos de idade e cerca de 20 anos de residência no bairro): Às vezes acontece de quando nós estamos no centro o pessoal gosta de falar do bairro, agora não sei porquê. Eu digo "Minha gente, pois eu ach o que ele é um bairro como qualquer um bairro aí". Só que o pessoal acha que o bairro Mutirão ele é mais, mais que todos os bairros. Eles acham que tem mais vândalos, de gente mau elemento que todos. Eu acho que todo bairro é assim, penso eu que é, não sei não. Agora dizer que tem..., tudo no mundo que acontece aqui é difícil acontecer com um pai de família direito trabalhador, só acontece mais é com os malandros.

Santana Neto (52 anos, foi uma das lideranças do MST, médico, foi prefeito de Juazeiro pelo PT (2009-2012)): É um dos bairros também mais violentos. Chegou a ser na cidade sinônimo assim de... coisa marginal mesmo. Eu estava uma vez num negócio no hospital e acho que estava com alguém, não sei, e fiquei fora, na recepção, e vi uma pessoa. Chegou, aí disse... e eu sabia que era de lá [do bairro] o cara. 'Tu mora onde?', ele disse outro canto. Eu saí e disse "tu não está mais morando lá no Mutirão não?" “Não, Santana, eu estou, é porque eu tenho vergonha de dizer senão o pessoal pensa logo que a gente é bandido".

Dona Sebastiana: Tem gente que para arrumar emprego lá embaixo nem diz que mora aqui no Frei Damião, que o povo às vezes não quer. Diz que é ladrão. É dois nomes, com a licença da palavra, ladrão e rapariga. É o tratamento que a gente ganha aqui. É essa a palavra, desde o começo, que aqui só mora esses dois tipos de gente. E no final das contas nemé, tem tanta gente boa aqui.

Além do que nos relataram nossos entrevistados, são ilustrativos do discurso corrente sobre o bairro Frei Damião os trabalhos de Silva (2010) e Pereira (2009). Neles, sem apresentarem qualquer informação empírica, os autores descrevem o local a partir das seguintes afirmações: "alto índice de desemprego", "grande número de trabalho 
infantil", "enorme incidência de prostituição, marginalização e grande parte da população desqualificada para o mercado de trabalho", "as famílias dos alunos são pouco estruturadas, com muitos filhos, falta de convivência familiar e muitas mães adolescentes", "comunidade carente", "bairro considerado pela UNICEF como de risco para crianças e adolescentes" (SILVA, 2010, p. 6-7), "alto índice de roubos e furtos como também a violência urbana", "evasão escolar que atingem altos índices no bairro" (Sic) (PEREIRA, 2009, p. 42 e 45). Esse é, sobretudo, o imaginário que foi constituído a respeito do bairro e de seus moradores.

Se atentarmos para a cartografia urbana do bairro Frei Damião, veremos que é distante da tradicional paisagem com a qual é comum se caracterizar as favelas/periferias brasileiras (com ruas tortas, sem sinalização, em áreas de declividade acentuada) e mesmo da maioria dos bairros de Juazeiro do Norte, construídos sem planejamento urbano. Desse modo, acreditamos que o imaginário de favela/periferia atribuído ao bairro foi constituído no próprio projeto e processo de criação de uma comunidade, ou seja, em torno do Movimentos dos Sem Teto e, posteriormente, perpetuado ao redor do espaço físico e social que se conquistou.

Como se pode perceber a partir dos enunciados proferidos em referência ao bairro e das ações estatais ali implementadas estrategicamente (estas últimas não analisadas aqui, Cf. FEITOSA, 2015), práticas discursivas e não-discursivas se imbricam na constituição do bairro Frei Damião como favela/periferia.

Cientes da possibilidade de serem associados à imagem de periferia/favela, as lideranças do MST se esforçaram para que o bairro não fosse assim caracterizado. Prova disso é a organização espacial adotada no bairro, que não surgiu de modo espontâneo. A disposição dos lotes de casas, dos quarteirões e a dimensão ampla das ruas foi planejada antes da construção das habitações. Para Chico Gomes: "O movimento procurou que não se tornasse um bairro de um amontoado de casa, mas um bairro de gente pobre, mas bem organizado" e houve "todo um trabalho para que se nascesse um bairro e não uma favela".

Quanto a esse aspecto, seu De Jesus, que participou da ocupação e mora no bairro há 17 anos, enalteceu (como também o fez Chico Gomes) a imagem de grandeza e organização do bairro a partir de elogios recebidos de ex-prefeitos municipais, que o viram como cidade: "É, agora ali é uma cidade", "Hoje o Parque Frei Damião é uma 
cidade, que Salviano [ex-prefeito de Juazeiro do Norte, 1983-1989 e 1993-1996] disse: 'deixe bagunçar o Mutirão da Vida não, que o Mutirão da Vida é uma cidade'”.

Como já se pode entrever, os sujeitos que desencadearam as ações que confluíram com a origem do bairro procuraram escapar da imagem de periferia que por ventura viesse a ser associada a ele. Fizeram isso ao criarem um bairro planejado. Entretanto, se mesmo assim não conseguiram ser percebidos como "bairro", enaltecem o bairro e o comparam com uma cidade. Não somente essas estratégias foram e são acionadas como negociação dessa imagística. Ela também é administra da, já que não se consegue refutá-la, a partir de nomeações diferentes e com sentidos diferentes do bairro, da segmentação do seu espaço físico e social e na atribuição de nomes distintos a cada um desses segmentos. Uma vez que não se consegue afastar a imagem de periferia do bairro, se afasta de determinados espaços do bairro para outros, criando, assim, hierarquias e processo de espacialização das diferenças socioculturais.

Por ora, vejamos os sentidos que guardam as diferentes nomeações que foram atribuídas ao bairro ao longo da sua história e que ainda coexistem informalmente.

\section{Sentidos das nomeações}

Se a produção do bairro Frei Damião, na cidade de Juazeiro do Norte, é relativamente recente, com pouco mais de duas décadas, sua produção social como bairro é ainda mais atual. Seu lugar na cidade sempre foi dúbio. Somente a partir de lei municipal do ano de 2009 (lei 3.535) foi que seu nome e seus limites foram definidos entre os demais bairros da cidade. Anteriormente, uma lei de 2000 (lei 2.569) o denominava de Mutirão I e II e sua demarcação não estava clara. Antes dessa, havia a lei 1.617, de 1991, que instituía os bairros da cidade. Nesta, o Frei Damião não estava listado, sendo sua área atual contemplada pelos bairros São José e Jardim Gonzaga, atualmente adjacentes. Além de seu território de hoje estar associado a esses dois bairros em 1991, sendo ora indicado pelo nome de um, ora pelo do outro, o que atualmente é bairro Frei Damião era denominado de Parque Mutirão da Vida, ou somente Mutirão e a referência a esse nome nos documentos legislativos sempre se dava tomando-o como bairro, mas sem mencionar a palavra, aplicando, em vez disso, o termo parque. 
Documentos oficiais consultados na Câmara Municipal de Juazeiro também o denominavam de Parque Nossa Senhora das Dores e houve uma tentativa, por parte do poder legislativo municipal, de denominá-lo de Parque Januário Macêdo. Em maio de 1993, quando a Câmara Municipal aprovou essa última denominação para o então Parque Mutirão da Vida, a associação de moradores elaborou um abaixo-assinado com 540 assinaturas de moradores e solicitou ao Prefeito Municipal que não sancionasse a lei. No abaixo-assinado, afirmava-se:

Insatisfeitos com essa informação os moradores, em peso, como provam as assinaturas que estamos enviando, se dirigem a V. Exa. para lhe pedir que faça o que lhe fôr possivel para não deixar que cometam conosco essa barbaridade. Nós gostamos do nome que o nosso bairro tem, e achamos bonito e cheio de significado, e queriamos, de todo coração, que ele não fosse mudado nunca. E se os senhores Vereadores, que segundo nos informaram, é quem determinam essas coisas acham que isso não pode ser, que o nome é feio ou inconveniente é por isso tem que ser mudado, - nós embora com muita pena porque, como dissemos, achamos o nome bonito e queriamos ficar com ele,- pedimos que pelo menos seja colocado o nome de alguém que diga alguma coisa para nós e tenha alguma coisa querver com a nóssa vida. Por exemplo, DOMVICENTE ARAúJO MATOS, ex.Bispo do Crato, que foi o doador do terreno em que habitamos e assim tornou possivel com sua generosidade pessoal, a formação da nossa comunidade. Esse nos poderiamos aceitar mais conformados. Mas um desconhecido total para nós, totalmente alheio à nossa vida, - por amor de Deus não! [Sic].

Como se nota nessa passagem, o nome Mutirão, ou Mutirão da Vida, tinha uma simbologia positiva para os que na época habitavam o bairro e estavam engajados no MST, já que apreendia o local como projeto coletivo das camadas populares de Juazeiro do Norte, algo pensado no manifesto "Projeto alternativo habitacional da população de Juazeiro do Norte", que propunha a constituição do local, como apresentado anteriormente. Portanto, essa denominação, ainda hoje muito usual, precede o próprio evento de ocupação.

Como consta em documento legislativo, foi em fevereiro de 1998 que houve a alteração do nome Mutirão para a designação atual de bairro Frei Damião. Mesmo com a mudança oficial, as duas denominações passaram a coexistir, sendo o local ora indicado como Mutirão, ora Frei Damião. O sentido do nome Mutirão entre moradores que não participaram da ocupação não corresponde ao sentido compartilhado por aqueles que dela participaram, como inclusive se pode notar em análises anteriores de interlocutores. Assim, para uma moradora que explicava a diferença entre as 
nomeações para um passageiro do ônibus que faz a linha para o bairro, Mutirão se refere à época em que o bairro não tinha ruas calçadas, escola, posto de saúde. Como ela dizia: o nome "é da invasão", época em que o bairro era uma "comunidade". Frei Damião, para ela, já se referia ao bairro, este tendo os equipamentos antes ausentes ${ }^{11}$.

Essa reflexão da passageira sobre as noções bairro e comunidade, ou seja, Frei Damião e Mutirão da Vida, retoma pontos tratados anteriormente, em que "bairro" toma um sentido oposto ao de favela (comunidade e Mutirão da Vida) ao significar uma área que fora planejada de modo a se distinguir de tal ("um trabalho para que se nascesse um bairro e não uma favela"). Por outro lado, a comparação do bairro com uma cidade também contribuiu com essa forma de percepção. Já o termo "comunidade" e Mutirão, para moradores como a passageira do ônibus mencionada acima, está mais para favela, periferia, do que para "bairro", do que para Frei Damião. Articulada com essa percepção acerca do que seja um bairro, Chico Gomes, ao se referir às condições existentes hoje na Baixa da Raposa, uma das áreas em que os moradores dividem o bairro, diz: "Hoje tá todo [o bairro Frei Damião], quase todo asfaltado, tem alguns trechinhos de rua que ainda não tá asfaltado, até na Baixa da Raposa hoje tem uma estrutura de bairro, posto de saúde, colégio, creche, enfim, uma linha de ônibus que atende precariamente, mas tá atendendo".

Essa apreensão do local por meio da categoria bairro, portanto, não deve escapar à análise. Após o surgimento do local, a partir da ocupação, a Prefeitura Municipal de Juazeiro do Norte demorou aproximadamente uma década para incluir o bairro Frei Damião na listagem geral dos bairros da cidade, o que ocorreu no ano 2000, embora ainda com o nome Mutirão da Vida. Dois anos antes, nomeara como Frei Damião a região que até então era alvo de distintas tentativas de nomeação. E, somente em 2009, portanto 19 anos após a ocupação e 11 anos depois da última alteração de nome, é que sua forma de denominação aparece nas leis da cidade.

Se Frei Damião dá um sentido de "bairro" ao que até então era uma "comunidade", estando essa palavra muito próxima de favela, essa passagem revela um deslocamento de sentido na forma de conceber e apreender o lugar. Porém, como

\footnotetext{
${ }^{11}$ A relação e al ternância entre as categorias bairro, comunidade e favela é constatada em Mattos (2012), Sá (2012), Leite (2001) e Freire (2008). Sobre as dubiedades do termo comunidade, ver Birman (2008).
} 
observaremos adiante, mesmo constando como bairro e com um nome novo, a imagem de periferia que recai sobre o local ainda é comum.

Mesmo diante disso, acreditamos que essas transformações redefiniram a cidade (embora o próprio movimento que deu origem ao bairro já tenha feito isso bem antes, em 1990), quando esta, a partir da Prefeitura Municipal, integrou o bairro ao seu espaço, atribuindo-Ihe um território e um nome determinado.

Os processos urbanos desencadeados em outras cidades brasileiras, embora tenham suas especificidades, podem ter influenciado na dinâmica apontada no bairro Frei Damião. No Rio de Janeiro, onde as favelas foram constituídas como questão/problema, elas passaram a constar nos mapas e cadastros da cidade, dos quais até então estavam ausentes, a partir do Plano Diretor de 1992 (BURGOS, 2006). Em outro momento, com o Programa Favela-bairro, constituído em 1993, um dos objetivos era: "'construir ou completar a estrutura urbana principal (saneamento e democratização de acessos) e oferecer as condições ambientais de leitura da favela como bairro da cidade" (Geap, 1993 apud BURGOS, 2006, p. 49).

Essas mudanças no nome do bairro Frei Damião, realizadas pelos poderes legislativo e executivo municipal, sinalizam tentativas de revisar o passado em relação ao presente e futuro. Como nos diz duas das nossas entrevistadas, sendo que a primeira participou do movimento que deu origem ao bairro e a segunda morando no local há cerca de 10 anos:

Nininha: [...] eles mudaram o nome, lógico que é um jogo político você tirar de Mutirão pra Frei Damião, é você mexer numa estrutura política de ideologia, as palavras elas têm um pesoideológico. Então, Mutirão você quer dizer um monte de gente que se junta, que se organiza, que são capazes e Frei Damião é um santo da cultura do povo. Então assim, o povo é devoto de Frei Damião, é um frade capuchinho, muito sensível às questões sociais, muito missionário, tem uma relação com Padre Cícero, com a própria cidade e com o imaginário popular. Então a mudança não foi porque o povo decidiu assim, não, foi uma mudança política, o conceito de..., um jogo de palavras que tem um poder ideológico muito grande, você afirma, você cria um nome ideológico e você coloca um nome da crendice popular. Isso pra o povo não perceber, porque se mudasse o bairro pro nome do prefeito, o pessoal logicamente, automaticamente não ia aceitar"

Suzana: Eu acho que Mutirão no começo era porque foi um monte de gente que veio morar aqui aí depois eu acho Mutirão ficou meio pra trás, já que tinha muita gente, então ficou Frei Damião [...]. Lucas: Quando as pessoas 
falam Mutirão, você acha que elas pensam o quê? Suzana: Eu acho que elas devem saber que é Frei Damião. Agora, não acho que elas sabem, agora não têm assim muita... não sei. Mas é meio chato porque a pessoa "Mutirão [dá ênfase ao pronunciar a palavra], sei lá, uma coisa de muita gente que faz bagunça. Lucas: Você acha que as pessoas veem assim? Suzana: Eu acho que é. Ah, é Mutirão, é perigoso, num sei o quê e tudo.

A argumentação de Suzana e de Nininha conflui com a exposição de Chico Gomes:

Valmir Domingo, quando foi vereador a primeira vez, fez um projeto para mudar o nome de Mutirão da Vida para Frei Damião, com a desculpa que Mutirão dá a ideia de greve, de coisa feia, de luta, de bicho feio. Aí vieram me dizer aqui: "Chico, a gente tem que ir pra Câmara de Vereadores pra impedir que seja mudado o nome de Mutirão pra Frei Damião". Aía casa aqui cheia de gente, eu digo: "Vocês querem saber de uma coisa, Frei Damião foi um grande missionário franciscano, capuchinho, pra onde Frei Damiãoia e ra um verdadeiro mutirão, era gente que só formiga, um puxava o cabelo, outro beliscava pra saber se ele era vivo ou se ele era um anjo ou o que que ele era". Eu digo: "Sabe o que vocês fazem, faz o seguinte, o importante é sua casa. Você tem al guma coisa contra Frei Damião?”, "Não", "Então deixa botar Frei Damião"12.

Todavia, Suzana admite que a mudança no nome do bairro não alterou a forma como as pessoas o veem. Ao perguntar-Ihe que imagem as pessoas têm do bairro, ela diz:

É como eu disse agora há pouco, que antes o povo via o bairro como Mutirão e via que era muito perigoso, ainda continua nisso, aquela visão de antigamente: “Aí pe perigoso porque num sei o quê, porque tem isso". E não é isso, porque em todo canto que você chegar vai ter sempre uma pessoa que faz o mal, outra pessoa que faz o bem e aqui tem isso, tem as pessoas que fazem o bem e as pessoas que fazem o mal. Lucas: Você acha que não mudou essa visão das pessoas? Suzana: Não.

Mutirão, lembremo-nos, é uma forma de mobilização e organização cooperada que fora adotada pelos movimentos sociais/classes populares para, entre outras coisas, construir habitações em áreas de ocupação (RIZEK; BARROS, 2006). A intenção daqueles que organizaram o MST também era essa, de construir as casas em "regime de mutirão", como está apontado no "manifesto Projeto alternativo habitacional da população de Juazeiro do Norte". Como nos diz Chico Gomes:

\footnotetext{
12 Frei Damião (1898-1997) foi um frade italiano, da Ordem dos Capuchinhos. Chegou ao Brasil em 1931 e aqui faleceu. Devotou-se a evangelização com a realização de Santas Missões por todo o Nordeste, tendo passado por Juazeiro do Norte (Disponível em: http://www.freidamiaodebozzano.org/biografia/. Acesso em: 27 jan. 2014).
} 
Todo assentamento de moradia lá em São Paulo onde se construía as casas se chamava de mutirão. Aíaqui nós fizemos essa adaptação, Mutirão da Vida. Agora, a sociedade não gostou. Eu digo a sociedade, o poder executivo e o poder legislativo da época. [...] Aí Carlos Cruz [prefeito à época] não gostou, a câmara, o [poder] executivo não gostou da palavra Mutirão, o legislativo. Que Carlos Cruz também ainda hoje quando a gente conversa, ele chama é o Mutirão da Vida. Carlos Cruz, doutor Mauro, Salviano [ex-prefeitos] também sempre fala Mutirão.

Como já ponderado, essa definição do nome para o povoado precede a própria ocupação da propriedade da Igreja, uma vez que surgiu no manifesto entregue ao Prefeito Municipal, durante a primeira manifestação que realizaram pelas ruas da cidade, em julho de 1990. De todo modo, Mutirão é uma nomeação que surge como sendo positiva ou neutra aos olhos de alguns moradores e participantes do MST; e a outros, negativa, acentuando a tônica do estigma. A palavra, assim, comporta uma ambiguidade para os moradores: por um lado, para aqueles engajados no MST, apresenta um sentido positivo ao encarnar uma história de luta e, por outro, sobretudo para aqueles que não integraram o MST, a palavra é lida a partir de uma orientação moral, do que ela encarna como sendo essa luta uma demonstração de despossuídos, de invasão da propriedade alheia, do próprio conflito que resultou. Se ainda é recorrente a utilização dos dois nomes, Mutirão e Frei Damião, é difícil especificar os motivos que levam os moradores a acionarem um em vez, ou mesmo em detrimento, do outro. Um recorte geracional pode ser atribuído, embora com cautela, uma vez que alguns dos residentes atuais no bairro não acompanharam seu surgimento ou não conhecem sua história. Se utilizarmos os dados do último censo (2010) e se considerarmos dentro do universo dos que não conhecem a história da ocupação aqueles que nasceram posteriormente ao surgimento do bairro (1990), portanto, os moradores que tinham até 20 anos de idade em 2010, estes representavam, naquele ano, $47,21 \%$ da população total do bairro (IBGE, 2016).

É ilustrativo desse aspecto geracional a seguinte narrativa de Aílton (20 anos de idade e morador do bairro), desenvolvida quando the perguntei sobre o que ele sabia da história do bairro:

Começou por um padre, mesmo, que isso daqui tudo era de um padre, não sei te falar como é o nome do padre, como é o nome da igreja, mas era de um padre que tinha umas pessoas que estavam loteando, roubando, não sei lá como era, invadindo os terrenos. Aío padre chegou a conversar com esse 
povo, que era da igreja também, e chegou a dizer: 'oh, eutenho uns terrenos em tal canto e tal e tal, vão lá que é seu, é de vocês'. Aícomeçou por isso, tá entendendo? Esses terrenos aqui não têm..., 'não essa casa tá em meu nome', a casa sim, do tijolo pra cima tá, mas o nome do terreno, não tem nome, aqui não tem nome de terreno não, tá no nome do padre esses terrenos tudo aqui. Não tem a escritura do terreno. Chegou a fundar mais por assim também, por as pessoas estarem querendo terreno, o padre adiantou e tudo. Bom, o que eu sei é isso.

Como se vê, contada por Aílton, a história do bairro é menos institucionalizada, o que a torna distinta da narrativa das lideranças à frente do movimento social que fundou o bairro. Ele desconhece fatos, como o movimento que mobilizou a ação de ocupação e o local onde ela se deu, e as relações nada fáceis com os líderes políticos e religiosos locais. Por outro lado, sua fala conflui com aquela de dona Sebastiana, a qual dizia como o povo que ocupou as terras da Igreja "ficou na história": ficaram "como vandalismo, como bandidos, como desocupados". Aílton oscila entre "loteando, roubando e invadindo os terrenos" que pertenciam a um padre para sugerir que o bairro surgiu a partir de uma ocupação.

Como já apontaram as análises de nossos interlocutores, as disputas em torno da significação do local a partir do nome a ele atribuído ou da apropriação do bairro por meio de seu nome, procura, a um só tempo, mas com participação de agentes distintos e até mesmo antagônicos, visibilizar a história e memória do local e de sua gente ou ocultar/negociar a condição de sua origem e de seu povo. Por um lado, agia o movimento social que o originou, por outro, a Cidade, sua representação políticoadministrativa oficial (a prefeitura).

Acreditamos que o entrelaçamento entre tantas práticas, enunciados e eventos constituíram e perpetuaram a imagem de periferia/favela na forma de conceber o bairro.

Como veremos a seguir, a segmentação do bairro Frei Damião em três territorialidades distintas também reflete essa imagística de periferia imputada ao local.

\section{Segmentações socioespaciais ${ }^{13}$}

\footnotetext{
13 Utilizo o termo segmentação por considerar que estratificação tem uma conotação de parcelamento de um todo, uma perspectiva macroestrutural. Por outro lado, pode levar a entender que estratos não se cruzam (um estrato não intercepta, não tem interseção com outro estrato). O termo estratificar também carrega um sentido de todo fixo (fronteiras rígidas), além de parecer ser substancializado, sobretudo em termos econômicos (distribuição desigual de bens materiais), o que cria o entendimento de que essa
} 
Como já mencionado, a área do bairro Frei Damião em que as habitações estão concentradas densamente, com aproximadamente $3,3 \mathrm{~km}$ de extensão e $200 \mathrm{~m}$ de largura, é dividida em três segmentos. No sentido norte-sul, eles estão dispostos na seguinte ordem: Vila Real, Frei Damião (mesmo nome do bairro como um todo) e Baixa da Raposa ou Baixa da Esperança. Cada uma dessas territorialidades tem características específicas, o que leva ao entendimento de que o bairro Frei Damião, como um todo, não é homogêneo.

Além das diferenças urbanas e do padrão arquitetônico das residências, das diferentes intensidades da vida social local (FEITOSA, 2015), como se observou antes, cada territorialidade tem uma gênese própria. A área conquistada pelo MST a partir da ocupação, bem como seu povoamento, tem início na territorialidade Frei Damião. Ali foram construídas as primeiras habitações dos cadastrados no movimento social, que foram se estendendo paulatinamente pelo restante da propriedade. A Baixa da Raposa, que recebeu essa denominação há muito tempo, foi povoada posteriormente, inclusive a partir de projetos habitacionais executados pelo Estado. A área denominada de Vila Real nunca pertenceu ao Movimento, mesmo sendo do patrimônio da Igreja e estando adjacente à área doada aos sem teto. Estando mais próxima da Avenida Padre Cícero e sendo mais valorizada economicamente, segundo nossos interlocutores, fora colocada à venda em 1991, uma vez que a Igreja temia que as pessoas do Movimento, que já habitavam a região doada, resolvessem tomá-la.

Essas particularidades de cada área dão margem a processos de diferenciação internos ao bairro. Mas estas diferenciações são produzidas também como negociação da imagem de periferia do bairro como um todo ${ }^{14}$, tanto é que além de serem

\footnotetext{
dimensão econômica é a causa por excelência da existência de estratos e diferenças nas sociedades. Isso pode ocorrer, mas nem sempre ocorre e nem sempre é a única causa do tipo de processo a qui em questão (ELIAS; SCOTSON, 2000). Já o termo segmentaridade parece mais aberto e pode ser articulado à noção de práticas sociais, que são múltiplas, incluindo a do pesquisador. As práticas sociais também são constituintes dos segmentos socioes paciais. O concei to de segmenta rida de ta mbém evita aquilo que Elias (2008, p. 122) denominou de "redução processual", a redução de "processos a condições estáticas", o que alguns conceitos às vezes fazem. É tentando levar a sério a proposta de Elias, de constituir "novos meios de falar e pensar" (ELIAS, 2008, p. 120), que entendo que a noção de segmentaridade tanto prioriza a relação quanto é, ta mbém, um conceito relacional.

14 Por "bairro como um todo" estou entendendo não necessariamente a definição estabelecida pela Prefeitura Municipal do que seja o bairro (definição oficial), mas uma que seja criada pelo pesquisador como unidade de análise a partir da interdependência existente entre diferentes segmentos socioespaciais dispostos hierarquicamente entre si. Com isso, evita-se cair em uma fragmentação exacerbada ou em uma totalidade inexistente, e evita-se desconsiderar que muitas vezes esses distintos
} 
segmentos de uma mesma região, essas territorialidades receberam nomes distintos e, com isso, sentidos diferentes.

Vale dizer que as pessoas se autodenominam como moradoras da Vila Real, do Frei Damião ou Baixa da Raposa, dependendo de onde moram, e o fazem se referindo a essas áreas como bairros. "Os outros se consideram mais Vila Real", comentou um interlocutor. Confluindo com isso, no material de divulgação dos festejos religiosos da capela de Nossa Senhora das Candeias, cuja capela está situada na territorialidade Vila Real, encontramos: "Somos uma das onze capelas que compreende a Paróquia de São João Bosco, localizada na Rua Poeta Vitorino Vicente entre os bairros Frei Damião e Vila Real" (Sic). Especificamente sobre a Vila Real, observou Pereira (2009, p. 44-45):

Notadamente percebemos no bairro Frei Damião, uma divisão interessante, alguns metros antes da antiga capela, mas precisamente na rua Manoel Tavares até a rua Poeta Vitorino Vicente, local onde começou o povoamento do bairro, existe um loteamento onde as pessoas dizem que não moram no mutirão, e sim moram na "Vila Real", mas nem o Instituto Brasileiro de Geografia e Estatística (IBGE) e nem a secretaria de infra-estrutura, tem alguma coisa registrada com essa denominação [...]. Rodrigues, (1989), mostra nesse loteamento é uma situação econômica por parte dos seus moradores um pouco melhor que o restante do bairro, que é percebida pelas estruturas das casas [...]. [Sic. Grifos meus].

A divisão da área do bairro não é apenas de ordem geográfica. A sucessão dessas secções representa, antes, clivagens diferenciadas de status sociais, apresenta fronteiras e estratégias de lutas simbólicas em que se procuram criar distinções e impingir, ao outro, símbolos de inferioridade, criando imagens de si e do outro (ELIAS; SCOTSON, 2000 [1965]; MATOS, 2004) entre as três territorialidades. Ou seja, as subáreas existem como uma escala de gradação, hierarquia de lugares - como apontado por Pereira na citação acima, na Vila Real "[...] as pessoas dizem que não moram no mutirão, e sim moram na "Vila Real'”. Isso parece indicar fronteiras simbólicas que são postas em luta e disputa entre os moradores. Residir em uma ou outra dessas áreas é ser associado a níveis diferenciados de prestígio, de esta dos de pobreza. Assim, a Baixa

\footnotetext{
segmentos estão situados uns em relação aos outros de forma hierárquica, es tabelecendo-se entre eles oposições/contrastes, constituindo-se imagens e autoimagens de distinção. Ao estarem dispostos hierarquicamente uns em relação aos outros, isso significa que, muitas vezes, (mas não apenas) eles surgem em oposição a uma imagem mais englobante/geral do bairro como periferia (ou seja, surgem como oposição/negociação a essa imagem). Portanto, a partir do contraste entre as distintas áreas há a instauração de uma interdependência entre elas.
} 
da Raposa é "a favela" por excelência, local de bandidos, como me disse certa vez um interlocutor. Outro contato em campo contou-me que ações assistenciais acontecem com mais frequência lá. "Essas coisas, só na Baixa da Raposa mesmo", comentou o barbeiro, em um bairro próximo ao centro da cidade, enquanto assistia a uma reportagem sobre apreensão policial de drogas e armas na Baixa da Raposa.

Enquanto isso, a Vila Real seria o local mais nobre, aristocrático, como sugere o próprio nome. Em relação a essa segmentaridade, conversando com uma amiga que reside na Baixa da Raposa, a mesma ficou surpresa quando comentei que a Vila Real, no mapa da prefeitura (cartográfica instituída como oficial do município), integrava o bairro Frei Damião. Tendo essa informação, disse que iria transmiti-la às amigas dela que residiam na Vila Real, o que me pareceu um comportamento de defesa às possíveis críticas feitas pelas amigas ao fato de ela morar na Baixa da Raposa, ou também para não deixar que a Vila Real seja eximida ou se exima de pertencer ao bairro Frei Damião.

Como já se pode notar, a polarização manifestada nas falas dos nossos interlocutores reside, especialmente, entre a Vila Real e a Baixa da Raposa. A primeira é tida a partir das "casas boas", "bem organizada", nas quais "a situação econômica dos moradores é melhor" do que no restante do bairro, onde "as pessoas dizem que não moram no Mutirão". Enquanto isso, a Baixa da Raposa é pensada como "baixa", com moradores de "classe pobre", onde "o povo diz que se juntou muitas pessoas que gostavam de pegar no que era dos outros, que vinha dos outros cantos, de São Paulo, desse mundo, e se escondia aqui", onde a situação "é o pior", com "gente considerado como mais ruim e tudo", chamada de Baixa da Raposa porque "raposa é um bicho sabido". Essas caracterizações, feitas em muitas das entrevistas por mim realizadas com moradores do bairro Frei Damião, surgem, muitas vezes, em contrates. Daí que nelas há um princípio relacional de complementaridade, um vínculo triplo, uma interdependência ou, para fazer referência direta ao estudo de Elias e Scotson (2000), essas áreas formam uma figuração.

Assim, a classificação, diferenciação e hierarquização que encontramos no interior do bairro Frei Damião, manifestada claramente ao se atribuir nomes distintos, marcos de fronteira e características a cada espaço, é também uma classificação, distinção e hierarquização das pessoas que ali residem. 
Entre as três territorialidades, os aspectos estéticos e de infraestrutura das residências dos moradores e a condição das ruas são decrescentes no sentido norte-sul, logo Vila Real - Baixa da Raposa. Mesmo que essas mudanças sejam visíveis ao longo da extensão do bairro e que existam pontos de demarcação utilizados pela maioria dos moradores para dividir as áreas, essas fronteiras, às vezes, são borradas, seja a partir de práticas sociais que operam outras segmentações, como é o caso das comunidades religiosas existentes com base nas capelas devotadas a santos católicos ou das falas dos moradores, que oscilam as fronteiras.

A imprecisão espacial (geográfica) e cognitiva (enunciado) pode ser entendida como uma forma de irmanar-se a um e rivalizar com outrem, criando e agenciando pertencimentos, erigindo fronteiras simbólicas, o que fica claro em relação à Baixa da Raposa quando os moradores se referem a ela como "lá pra cima", "lá" e "lá em cima". Essa dificuldade em criar limites precisos de fronteira ou o tensionamento desses limites se dá, sobretudo, entre a Vila Real e o Frei Damião, embora a maioria dos moradores utilizem a Primeira Rua ou Rua da Capela de N. Sra. das Candeias como marco. Assim, parece haver um espaço em que a fronteira está borrada. A fronteira é mais clara entre o Frei Damiãoe a Baixa da Raposa, não somente porque tem a caixa d'água que abastece o bairro como delimitação, mas também porque o asfalto, que até então acompanhava praticamente todas as ruas, dá espaço a calçamentos, quando existentes, a partir da Baixa da Raposa.

A arquitetura e estrutura das casas também atuam como sinalizadores dessas diferenças sociais. Não quero dizer com isso que não existam, na Baixa da Raposa, casas com o mesmo padrão das que há na Vila Real. O que destaco é que enquanto na Vila Real a predominância é de casas com muros altos, cerca elétrica, garagem e fachada recoberta com cerâmica, na territorialidade Frei Damião e, de modo mais acentuado, na Baixa da Raposa, esse padrão constitui quase que exceção. Assim, predominam na Baixa da Raposa casas de arquitetura mais simples, rudimentares até mesmo, sendo que algumas foram construídas a partir de programas habitacionais financiados com recursos públicos.

Essa questão da flutuação ocasional dos limites entre as três territorialidades revela a friç̧ão entre diferentes mapas nativos, inclusive à revelia do mapa oficial elaborado pela Prefeitura Municipal. Ao tempo em que há um consenso entre os 
moradores sobre onde se localiza o bairro Frei Damião, no retângulo onde as habitações dos moradores estão mais densamente concentradas, por parte de alguns deles há um desconhecimento, ou conhecimento, sobre o pertencimento ou não da Vila Real à área do bairro. Podemos citar dois exemplos ilustrativos disso. O primeiro diz respeito ao mapa desenhando por seu Olavo e fixado em sua mercearia, localizada na territorialidade Frei Damião. Nele, o território ocupado pela Vila Real integra a região do bairro, mas essa territorialidade não tem, ao contrário das demais, a indicação de seu nome no mapa, apenas estão sinalizados os pontos de inflexão que a demarcam. Já noutra cartografia nativa, a autora, moradora da Baixa da Raposa, distingue cada uma das três territorialidades. Porém, destaca apenas a Vila Real como bairro, escrevendo "Bairro Vila Real", restando, portanto, apenas Frei Damião e Baixa da Raposa como áreas que compõem o bairro Frei Damião (MELO, 2013).

Também para esse caso, poderíamos considerar para sua explicação o fator geracional, uma vez sendo seu Olavo um senhor de idade avançada, antigo habitante de Juazeiro do Norte e morador do bairro há mais de uma década. Enquanto isso, Melo tinha pouco mais de 20 anos de idade e morava no bairro há menos de uma década. Todavia, aqui também a aplicação desse recorte apresenta limites, como também já ponderamos para o caso do acionamento dos nomes Mutirão e Frei Damião. Se o primeiro mapa parece mais plausível diante do segundo (e inclusive corresponder parcialmente a definição oficial estabelecida pela Prefeitura Municipal), tendo como base o provável conhecimento histórico acumulado pelo ancião que é seu autor em contraponto à aparência juvenil de quem elaborou o segundo, a seguinte fala de seu De Jesus o tensiona.

Aífoi e surgiu o loteamento, venderam para a imobiliária, a imobiliária loteou [...]. Hoje nem é Parque Frei Damião, lá chama Vila Real. Mas que a igreja Nossa Senhora das Candeias não é no Parque Frei Damião, é na Vila Real. Parque Frei Damião é da estrada, da rua Poeta VitorinoVicenteà estrema de Barbalha [município que faz fronteira com Juazeiro], [a rua] Francisco Martins de Souza é o nascente e [a rua] Manoel Tavares Lopes ao poente.

Seu De Jesus tem tanto a idade equivalente à de seu Olavo como esteve engajado nas ações do MST, ou seja, também é portador de um conhecimento histórico. 
Diante dessas diferentes leituras, significações e mapas do bairro, cabe dizer que não é nosso objetivo encontrar um consenso sobre um bairro verdadeiro e real. Interessa-nos pensar o que essas diversas elaborações dizem sobre o local e sua gente.

Em vista dessa dinâmica de segmentação social e física do bairro Frei Damião, com Bourdieu (2012), podemos indicar que ali são mesclados, de maneira confusa e dissimulada, os espaços sociais e os espaços físicos. Assim, a figuração Vila Real-Frei Damião-Baixa da Raposa é a expressão de modos de objetivação e subjetivação das posições sociais que se exprimem/ "traduzem" na e pela cartografia. É a expressão e articulação do estigma e das diferenças socioculturais no espaço. São as diferentes formas de espacialização de relações sociais distintas (SÁ, 2012). Esse espaço é mapeado, tanto nas estruturas espaciais como nas estruturas mentais, a partir da distribuição desigual dos agentes e da distribuição dos bens e serviços, privados e públicos. É a relação entre essas distribuições aolongo da história que define o valor das diferentes regiões do espaço social reificado (BOURDIEU, 2012).

Se essa diferenciação se dá de acordo com a "distribuição dos bens e serviços, privados ou públicos" (BOURDIEU, 2012, p. 160), no caso dos recursos públicos existentes no bairro, estes se concentram nas territorialidades Frei Damião e Baixa da Raposa. São serviços especificamente destinados a localidades de "vulnerabilidade social". Assim, encontramos o CRAS, o CAIC, a Praça da Juventude, as ruínas de onde funcionaria uma "delegacia da mulher", o prédio construído para sediar a Cozinha Comunitária, o Projeto Atleta Cidadão e o Segundo Tempo, todos localizados nessas duas regiões do bairro. São, de fato, equipamentos, mas que carregam a marca de destinados especialmente para áreas de "risco social".

Essa segmentação do espaço físico revela uma segmentação social. Tal dinâmica pode ser observada, inclusive, nas nomeações que as diferentes áreas recebem. 0 fundamento dessa lógica se dá, em muito, por contraste.

Ao mesmo tempo, a de se considerar que a Vila Real é, muitas vezes, apresentada como bairro separado do Frei Damião, ou seja, como um bairro em si. Entendemos que essa distinção da Vila Real e sua "externalidade" do bairro Frei Damião não se deve apenas a fatores materiais, como o patrimônio arquitetônico e a condição financeira de seus moradores, mas também está associada ao seu não pertencimento histórico ao bairro, ao contrário das demais territorialidades. Ou seja, a forma como surgi u, a partir 
da venda de parcela da propriedade que então pertencia à igreja de N. Sra. das Dores e não como fruto da ocupação liderada pelos membros do MST, reforça essa distinção. Assim, o que é "externalizado" (LEITE, 2001) do bairro não é a favela, mas a área nobre. Como já afirmaram Elias e Scotson (2000, p. 27): “Com frequência, os próprios nomes dos grupos que estão numa situação de outsiders trazem em si, até mesmo para os ouvidos de seus membros, implicações de inferioridade e desonra". Embora não tenham sido, no bairro Frei Damião, os "estabelecidos" que designaramas demais áreas, a forma como a designação "Baixa da Raposa" é lida, diz muito da estigmatização da qual são alvo seus moradores. Como afirmou Aílton, um jovem de 20 ano e morador do bairro: "Um dos bairros mais antigos é esse daqui [Frei Damião] e Baixa da Raposa. Baixa da Raposa porque baixava, parecia uma baixa mesmo, só tinha gente mais assim, mais classe pobre mesmo, mais menino e tudo. Aí foi crescendo e crescendo, aí findou Baixa da Esperança".

O próprio nome do local, Baixa da Raposa, não é benquisto por seus moradores. Por esse motivo, é provável que tenha surgido a denominação Baixa da Esperança. Enquanto as demais territorialidades apresentam nomes tradicionais (Frei Damião), e mesmo aristocrático (Vila Real), a Baixa da Raposa está associada a um mamífero predador conhecido por ser astuto e matreiro em suas habilidades na caça, apresenta uma projeção da natureza sobre o humano a partir da associação tanto ao animal raposa como ao perfil topográfico da área, uma baixa.

Dona Sebastiana: Agora o povo diz que é porque lá se juntou muitas pessoas que gostavam de pegar no que era dos outros, quevinham dosoutros cantos, de São Paulo, como foram pegas pessoas que vieram desse mundo e se escondiam aqui. Aí vai discriminar as pessoas que estavam aqui, não, eles vinham se esconder aqui porque sabiam que aqui era mais difícil de serem encontrados. Aívinha e ficava no meio da gente. Aíchamaram lá de Baixa da Raposa porque raposa é um bicho sabido [risos].

Aílton: Aí o bairro chega a ser muito desconsiderado pelas pessoas que não conhecem. Lucas: Tu acha que principalmente em relação à Baixa da Raposa? Aílton: Ah, a Baixa da Raposa é o pior. Oh, daqui de frente ao CAIC pra cima é tipo considerado como pessoas de bem e tudo. Mas oh, "aconteceu de trás do CAIC para lá", é mais gente considerada como mais ruim e tudo.

Ressalte-se que essas nomeações, sejam depreciativas ou elogiosas (se não é um elogio dizer de uma vila que ela é real), "[...] só fazem sentido no contexto de relações 
específicas entre estabelecidos e outsiders" (ELIAS; SCOTSON, 2000, p. 27) e só funcionam pela existência de um desequilíbrio de poder (Ibidem.). Acrescente-se a isso o fato de que, pelo aspecto relacional que as caracteriza, elas, as nomeações depreciativas e elogiosas, contribuem para a constituição da autoimagem de ambos os grupos, embora criando crenças distintas.

Essa relação de figuração e de imagem e autoimagem existente entre as três territorialidades do bairro não é inerente a elas, mas se estende para além do domínio interior do bairro Frei Damião, uma vez envolvendo também o bairro como totalidade e a cidade. Essa ligação fica evidente quando os moradores do bairro Frei Damião se referem à cidade a partir de termos como: "rua", "lá embaixo", "lá fora", "no centro".

Interessante notar como há, no bairro, múltiplas apropriações a partir dos nomes e seus significados, tanto em relação ao nome do bairro, como observamos anteriormente, como em relação ao nome Baixa da Raposa. Para alguns, como Chico Gomes, esse nome foi atribuído por Padre Cícero, como mencionado em passagem citada, e a raposa não seriam os moradores, mas o "governo", já que essa área foi repassada à Prefeitura Municipal pelo MST. Já para seu De Jesus, o nome surgiu do fato de ter havido no local um homem que caçava raposas e depois vendia o couro do animal no comércio da cidade.

De toda forma, o que nos interessa é como o nome é significado atualmente. Seu sentido de pessoas "sabidas", estendido das habilidades do animal, soa como pejorativo. Tanto é que recentemente os moradores passarama adotar o nome Baixa da Esperança. O novo nome já foi absorvido pelos moradores de tal maneira que fora utilizado no panfleto de divulgação das festas de Santa Edwiges, em 2013.

\section{Considerações finais}

O artigo objetivou compreender a inserção social do bairro Frei Damião na cidade de Juazeiro do Norte e o lugar (ou não-lugar) que na cidade o referido bairro tem. Adotamos como referência o movimento social que o projetou e a forma como o processo ocorreu. Se, por um lado, a produção social de um lugar, na cidade, ocupado pelo bairro escapa (mesmo que ele esteja grafado em uma das formas usuais de denominar o local, Mutirão) a esse elemento histórico, embora esse fator seja 
transmitido difusamente de geração a geração, o lugar do bairro é atualizado pela ideia de pobreza, violência e risco social. Nesse caso, o acesso à moradia não é o acesso à cidade (MENEZES, 2013). Ao contrário, sua inscrição na cidade se dá como não-cidade, is to é, como o Outro do imaginário urbano, como periferia, favela ou formas correlatas.

Seja em função do movimento que o originou, dos conflitos daí resultantes e da "vulnerabilidade social", o lugar do bairro Frei Damião parece ser a não-cidade ao estar inscrito simbólico e espacialmente às margens da cidade.

\section{Bibliografia}

BIRMAN, Patricia. Favela é comunidade? In: MACHADO DA SILVA, Luiz Antonio (Org.). Vida sob cerco: violência e rotina nas favelas do Rio de Janeiro. Rio de Janeiro: Nova Fronteira, 2008.

BOURDIEU, Pierre. Efeitos de lugar. In: . (Coord.). A miséria do mundo. 9 ed. Petrópolis: Vozes, 2012.

BURGOS, Marcelo Baumann. Dos parques proletários ao Favela-Bairro: as políticas públicas nas favelas do Rio de Janeiro. In: ZALUAR, Alba; ALVITO, Marcos (Orgs.). Um século de favela. 5 ed. Rio de Janeiro: Editora FGV, 2006.

DELLA CAVA, Ralph. Milagre em Joazeiro. Rio de Janeiro: Paz e Terra, 1976.

DURHAM, Eunice Ribeiro. A sociedade vista da periferia. In: THOMAZ, Omar Ribeiro (Org.). A dinâmica da cultura: ensaios de antropologia. São Paulo: Cosac \& Naify, 2004.

ELIAS, Norbert. Introdução à sociologia. Lisboa: Edições 70, 2008.

ELIAS, Norbert; SCOTSON, John L. Os estabelecidos e os outsiders: sociologia das relações de poder a partir de uma pequena comunidade. Rio de Janeiro: Zahar, 2000.

FEITOSA, Antonio Lucas Cordeiro. Práticas sociais e espaço urbano: diferentes cartografias e representações sobre o bairro Frei Damião. Dissertação (Mestrado em Sociologia) - Universidade Federal da Paraíba, João Pessoa, 2015 [2014].

FREIRE, Leticia de Luna. Favela, bairro ou comunidade? Quando uma política urbana torna-se uma política de significados. Dilemas: Revista de Estudos de Conflito e Controle Social, Rio de Janeiro, v. 1, n. 2, p. 95-114, 2008. 
IBGE. Censo demográfico e contagem da população. Disponível em: https://goo.gl/2649BS. Acesso em: 10 jan. 2016.

KOWARICK, Lúcio. Movimentos urbanos no Brasil contemporâneo: uma análise da literatura. Revista Brasileira de Ciências Sociais, São Paulo, v. 1, n. 3, p. 38-50, 1987.

LEITE, Márcia Pereira. Grajaú, memória e história: fronteiras fluidas e passagens. Cadernos Metrópole, São Paulo, n. 5, p. 91-125, 2001.

LIMA, Raimunda Machado. O Movimento dos Sem-Teto: construindo uma história de Juazeiro do Norte 1990 a 1999. Trabalho de Conclusão de Curso (Especialização em História do Brasil), Universidade Regional do Cariri, Crato, 2001.

MACHADO DA SILVA, Luiz Antonio Machado da. A continuidade do "problema favela". In: OLIVEIRA, Lúcia Lippi (Org.). Cidade: história e desafios. Rio de Janeiro: Editora FGV, 2002.

MATTOS, Geísa. A favor da comunidade: modos de viver a política no bairro. Campinas: Pontes Editores, 2012.

MATOS, Teresa Cristina Furtado. Notas sobre o conflito e a auto-imagem em Norbert Elias. Política \& Trabalho, João Pessoa, ano 20, n. 20, p. 229-245, 2004.

MELO, Ana Ruth de. Jiu-jítsu como um espaço de formação cidadã no bairro Frei Damião. Texto apresentado para exame de qualificação de monografia (Graduação em Ciências Sociais), Universidade Regional do Cariri, Crato, 2013.

MENEZES, Eduardo Diatahy Bezerra de. Padre Cícero e Floro: testamento e espólio (Apresentação histórica). In: TJCE (Org.). Execução do Testamento do Padre Cícero Romão Baptista e Inventário do Dr. Floro Bartholomeu da Costa: documentos em facsímile. Fortaleza: Imprensa Oficial do Estado do Ceará, 1997, v. 1.

MENEZES, Marluci. Quando ter casa nem sempre significa alterar uma situação de periferia. In: Encontro Anual da ANPOCS, 37, 2013, Águas de Lindoia.

PEREIRA, Cícero Alcione Soares. Análise sócio-espacial do bairro Frei Damião: o Mutirão de Juazeiro do Norte-CE. Monografia (Especialização em Geografia e Meio Ambiente), Universidade Regional do Cariri, 2009.

RIZEK, Cibele Saliba; BARROS, Joana da Silva. Mutirões autogeridos: construindo e desconstruindo sociabilidades. In: FRÚGOLI JR. Heitor; ANDRADE, Luciana Teixeira de; PEIXOTO, Fernanda Arêas (Orgs.). As cidades e seus agentes: práticas e representações. Belo Horizonte: PUC Minas/Edusp, 2006. 
SÁ, Leonardo Damasceno de. Favela, comunidade ou bairro? A espacialização das relações sociais na perspectiva de jovens surfistas do Titanzinho. In: Encontro Anual da ANPOCS, 35, 2011, Caxambu.

SILVA, Maria Jaqueline Ferreira da. O programa "Mais Educação" como uma política pública de inclusão social no CAIC - D. Antonio Campelo de Aragão. Monografia (Especialização em Gestão e Avaliação da Educação Pública) -, Universidade Federal de Juiz de Fora, Juazeiro do Norte, 2010.

VELHO, Gilberto. Projeto e metamorfose: antropologia das sociedades complexas. 2 ed. Rio de Janeiro: Jorge Zahar Ed., 1999.

ZALUAR, Alba; ALVITO, Marcos. Introdução. In: . (Orgs.). Um século de favela. 5 ed. Rio de Janeiro: Editora FGV, 2006. 